\title{
Symposium Review of
}

\section{Unser Leit: The Story of the Amish \\ by Leroy Beachy}

\section{Editor's Introduction}

Absolutely nothing about Amish history can be compared to the mammoth two volume set Leroy Beachy has compiled. Beautifully cased, these two sets feel like a treasure in your hands. But the contents are the real value. A lifelong project, this book is readable and beautifully illustrated. I have been surprised to hear from the historically un-inclined among the Amish and Amish-Mennonites how this volume drew them in and kept their attention.

What Leroy Beachy has done is set Amish history in a narrative style that is culturally informed in nuanced ways too numerous to list. For one, the history reads like a story, which is exactly the way Amish often frame ideas, whether in sermons, periodical articles, or even gossip. At another level, Amish conceive of their history as not just who did what, but in terms of lineage. As Werner Enninger (1986) has stated, with such a lapse in time since the Amish and Anabaptist movements began, “...the procreational chain has assumed the status of the predominant category in which historical continuity is perceived” (127). Fittingly, the second volume contains pages upon pages of genealogy at the time of the Atlantic crossing. As a final example, also based on Enninger's research, Amish texts that are expressive texts do not revel in the emotions of autonomous individuals, but find voice in intersubjectivity and shared convictions and beliefs. Unser Leit is an expressive, emotional text, one that rallies readers around shared empathies and cementing conviction in Amish readers for the veracity of where they have come from and what they are upholding today.

Because this book was written for the Amish, it was fitting to invite Amish to review it. Crist Miller is a resident of Holmes County, $\mathrm{OH}$, and gives tours of the Amish \& Mennonite Heritage Center's Behalt mural of Anabaptist history. Anna Raber is a Holmes County resident, a former teacher, and author of many short articles. Christopher Petrovich is a convert to the Amish whose training is in theology. His work appeared in JAPAS 1(1).

—Cory Anderson, JAPAS co-editor

\section{Reference}

Enninger, Werner. 1986. “The Theme of Ethnicity in the Literature of the Old Order Amish.” Pp. 115-36 in Studies on the Languages and the Verbal Behavior of the Pennsylvania Germans I, edited by Werner Enninger. Stuttgart: Franz Steiner Verlag. 


\title{
Summary of Unser Leit
}

\author{
Crist Miller \\ Old Order Amish \\ Holmes County, $\mathrm{OH}$
}

Unser Leit: The Story of the Amish is a must read for anyone that is interested in the Amish or Anabaptist history. Who are they? Where did they come from? These two volumes are a fascinating account long overdue of exploration of the Amish in Europe and immigration to North America, persecution of the Amish in Europe, and many other ordeals they encountered on both sides of the ocean. This thorough study and research of over twenty years in the making consists of nine chapters, plus all illustrations were done by the author.

Going through this book's chapters, you will find more Amish history than in any other book on the market. There is also an index of Amish immigrants of the 1800s. Why was there a falling away from the Amish, mostly in the 1900s? You will read all about this in "Century of Division"; also, all the names of Amish immigrants to the New World. Division after division started mostly after the appearance of the radio, telephone, tractor, electricity, automobile, and television, all of which were prohibited by the Old Order Amish.

Reading through these chapters, I will bring out some of the highlights of the The Story of the Amish. Chapter one, "Faith under Test," is truly the right heading. Starting around 1635, there was a new wave of persecution of Anabaptists of the Canton Zurich. Also at that time was the birth of Ulrich Müller, the founder of the Amish. Read all about the execution of Hans Landis. Persecution was so severe that the Anabaptist refugees started moving to new homes in Alsace and the Palatinate. Many Anabaptists had their property confiscated. Anabaptists started holding worship services in an abandoned castle. After this was forbidden, they began to hold their meetings outside the village in hedges, gardens, and fields.

How did the Amish start? Where did this movement start? Where did the name Amish come from? Who was Jacob Amman and where did he come from? These questions are all answered in this well written account in chapter two, "A New Beginning," on how this all started in the late 1600s. At this time, Anabaptists started increasing by the hundreds; they were increasing so fast, the authorities started to turn a blind eye to the presence of Anabaptists in their communities. This is the time when Jacob Amman, Hans Reist, and more Swiss Brethren followers had their disagreements. There are many, many comments about the lives of Amish and Mennonites through this time.

When reading through chapter three, "Oh!—But for a Home," you will note that Swiss Anabaptists were not welcome in their homeland, so they needed to search in secluded areas farther north on French and German lands. This chapter will bring you much knowledge of Amish history, including the three last Amish bishops in Salem, France. Read about the hard 
working Anabaptist living a practical, authentic, godly life.

In chapters four, "Pennsylvania_-Ho!” and five, “On the Move-Again,” you will read about the Amish coming to the New World and moving along the frontier. William Penn, a Quaker from England, was granted ownership of 40,000 square miles of real estate which is almost the size of Pennsylvania today. On this tract of land is where the Amish coming from Europe started to settle. You will have a chance to read who all the other immigrants were coming the same time simply to enjoy the same freedoms and rights as the Amish and Mennonites.

Read about the Anabaptist's singing on an ocean voyage from the hymnal, the Ausbund. Once in the New World, these immigrants met with lots of work: clearing the forests for farming, building houses, producing bricks, and manufacturing farm equipment. The author writes an account of an Amish man that refused an offer of a thousand acres of land by a proprietary agent in 1720 .

Delaware Indians bartered their lands south of the Blue Mountains for kettles and guns. Pioneering along the Irish Creek, Jacob Burkey made a welcome discovery-Amish neighbors! By 1737, the Amish are building log cabins, so there was rail splitting and fence building. Included in this chapter are the names, dates, and ports of arrival of immigrants in the 1700s. Some of these were the first to settle a place.

Unser Leit [meaning our people] gives another splendid account of the story of the Amish: commitment to the non-resistance teachings against the forces of evil. The terrifying outburst of Indian attacks and the American Revolution brought about an extensive migration of Amish to the unbroken wilderness of southeastern Pennsylvania. How did the Amish deal with the ongoing rebellion against the King of England? You will find out, plus about the many hardships the Amish endured in this well-written account. Anabaptists who refused to fight in the military had their farms and chattel confiscated. In 1777, the Revolutionary Council passed an act that all white males past the age of eighteen must take an oath of renunciation of the British Crown; persons taking the oath were given certificates to that effect. Without the certification such privileges as buying or selling land, possessing firearms, etc. were suspended.

Many Amish in eastern Pennsylvania, according to the author, suffered the loss of goods by the army when men pillaging for necessities took food and clothing to supply its men. However, this is when the Conestoga began to be built. This wagon building thrived for well over a century. One of these wagons is on display in the barn at the Amish and Mennonite Heritage Center near Berlin, Ohio.

Chapter six, “To the Wilderness,” tells you about Ohio becoming a gateway to the West for the Amish settlers from Pennsylvania and those directly from Europe. There is also an account by the author on Jonas Stutzman, the first Amish pioneer in Holmes County, settling near Walnut Creek in 1809. He also tells about the chair built by Mr. Stutzman for Jesus to sit in, 
whom he expected to return in 1853. This chair is on display at Behalt, the Amish and Mennonite Center near Berlin, Ohio.

Unser Leit refers to many Amish settlers in Holmes County in the late 1800s. One such person was Abe S. Yoder, coming from Grantsville, Maryland, to the Winesburg, Ohio area. He had been ordained a minister in 1884 and later as bishop in 1914. Bishop Yoder was married to Mattie Oswald, the only Oswald to remain Amish after the split in 1865. Also you will read about an Amish community founded in 1819 in southwestern Ohio in Butler County. Another settlement was founded in Fairfield County, Ohio, in 1829. Toward the end of this chapter, there are accounts of disasters hitting the Holmes County settlement.

Chapter seven, “The Atlantic Bridge,” contains loads and loads of information on Amish immigration from Europe to North America and then moving around to different places once they were here in the New World. The setting is now in the early 1800s and the Amish are on the move west across the Atlantic. They are now starting to settle in Somerset County, Pennsylvania; Ohio; further west; and also north to Canada. Hundreds of immigrant names are mentioned for coming to America, including where they settled and their material keepsakes they brought along. One of the largest groups of Amish ever to sail from Europe to America arrived at Baltimore in July of 1832.

In this chapter, you'll have to read the article about the Gingerichs and the Swartzentrubers immigrating from Mengeringhausen, Germany. It also tells you about the crooked church steeple in Mengeringhausen. Amish at this time settled in Fulton County in northwestern Ohio and Butler County in southeastern Ohio.

If you are Amish or of Amish background, you will most certainly find your ancestors in this chapter. At the end of this chapter, there is an index with names, dates, and ports of arrival of immigrants. In addition, there is a listing of where many of them first settled.

The purpose of chapter eight, "Reasons to Believe,” is more or less to follow through with the different events, ideas, and processes that have shaped the Amish faith and how it conforms or differs with that of other Christians or non-Christians. Also deeply embedded in the Amish conscience is a concept of sin and its effect on humanity. This chapter will explain to you how the Amish ordain ministers, bishops, and deacons. He also gives information on ministerial duties, the Amish way of life, and the Ordnungsbrief (standard of practice) of different time periods. The author has written well on the ban [shunning], evil habits, pride, cutting of hair on head or beard, eating, drinking, etc. Firearms were prohibited by the Amish when they were still in Europe. After coming to America, there was a gradual toleration of firearms. When you are done reading this chapter, you will surely have a lot of knowledge on the Amish way of life.

In the last chapter, “Century of Division,” read how and why all these divisions among the Amish were formed. In the beginning of the twentieth century, there was only one Amish congregation. The inventions of more modern technology were the start of breaking away from 
the Old Order Amish in the early 1900s. Telephone, electricity, automobile, tractors, radio, and TV: these were all prohibited by the Old Order Amish. At present, there are eleven affiliations of Amish in Holmes County and many Amish-Mennonite and Mennonite churches, too. The author has well documented how this came into being. Read all about it in Unser Leit: The Story of the Amish. All nine chapters will give you a much better understanding on who the Amish are.

\section{Review \#1: An Inside View, or, As I See It}

Anna Raber

Old Order Amish

Holmes County, $\mathrm{OH}$

Amish appreciate quality workmanship, which is evident when one picks up the first volume of Unser Leit. The inside cover Leroy illustrated foretells the pictorial history given with its written counterpart. Of particular benefit are the illustrations of architecturally correct buildings and historical items no longer in regular use.

In Leroy’s search for Amish beginnings, almost all references were found under "the Amish Division” chapter. His research shows that some sources about Amish origins are incorrect: "If the Amish had emerged as a division of an earlier organized body as has been commonly assumed, then both groups should be expected to have shared the same family surnames” (iv). Contrary to an Amish myth, the division was not between Jacob Amman and Menno Simons. The first major disagreement that led to division was between Jacob Amman and Hans Reist, on the article of shunning. Jacob Amman's supporters were called Mennonites until they entered the New World, where “Amish” was no longer an undesirable label.

Leroy does well in clarifying certain points that might confuse the reader in the pages addressed "To The Reader" before the onset of the account. He explains terms, the intent of the book, the difference in origin of the three groups of Swiss Brethren Anabaptists (Zuricher, Emmentaler, and Oberländer), and other topics that further the readers' abilities to understand the history. A quick reference help is the list of names and locations in the outside margin of each page that refers to names mentioned in the body text. A complete index is given at the end of each volume.

Unser Leit is written in a way that engages more than audiences of historians and sociologists. Part of its intent was "to strengthen the conviction" of the Amish who read it. It is not light and fluffy like Amish romance novels, a style that would devalue its position as an historically accurate and religiously sound book. Its reading gives one more appreciation for one's heritage and motivates a desire to uphold it. 
Unser Leit is not in the Christian Inspirational genre or among the works of scholars. It wasn’t meant to be either. If styled after either genre, it would have deflected its intended audience, "unser Leit" (our people). Leroy has a lot of footnotes, but sources were not always recorded as well as they should have been, an error he recognizes and aimed to improve once realized. Do the Amish care? We expect a man from our community to write an honest evaluation of our history without the perfect record of "footnotes" and a "bibliography." All the Amish should find Unser Leit readable in its accurate portrayal of the true essence of "the Amish.”

There is a population of Amish that will likely read Unser Leit but will never pick up a scholarly work. To compare Unser Leit to other works about the Amish written by outsiders or men of education is like the comparison of homemade bread to store bought bread. Both are bread, but the homemade, although preferred by a percentage, is scorned or snubbed by others. One comparison is An Amish Paradox by Charles E. Hurst and David L. McConnell. It is not a history, but serves well as an example. An Amish Paradox was well-researched, written, and presented, and is accurate, but the authors did not have the feel-they weren't steeped in Amish culture and hadn't lived it. As an example, Leroy writes that in the late 1700s and early 1800s, all the single men and boys seemed to "lose no time in finding a companion," a trite expression when reading hundreds of immigration accounts. Perhaps Leroy was trying to avoid overusing the simple term "married," which would better have suited a book devoted to a more proper, scholarly history.

Items of interest bring the characters to life, giving a personality to the names. Two examples are:

1. “One Muhlhofen man, Daniel Holly, was known for his unusual strength. One account tells of him carrying a donkey laden with baggage across a stream, another of breaking the horns off a vicious bull” (v. 1, 190).

2. Henry Stutzman was determined to build his home on top of his artesian well to provide $55^{\circ} \mathrm{F}$ water to his household all year. After a giant slab of stone from a local quarry, which was meant to be the foundation, sunk in the quicksand surrounding the well, Henry ordered a double platform of walnut logs forty-two feet in length to be constructed. It held and the house built around 1830 still existed at the time Unser Leit was written. Henry also fortified his Ausbund hymnal with 59 decorative brass studs (v. 1, 438).

Unser Leit contains all aspects of Amish history, yet focuses on Ohio and the history of the Ohio Amish, also the home of the author.

The Anabaptists or Amish had a preference for Froshauer Bibles and packed them along on the arduous journey overland and across the Atlantic Ocean to their destinations in Pennsylvania, Ohio, and other eastern states. The Froshauer is not in common use among the Old 
Order Amish in Holmes County today, making one wonder when and what influence converted the Amish to Martin Luther's translation of the Bible.

Leroy honestly portrays the Amish in their strong points and in their inconsistencies. Amish are thought to be nonresistant, honest, and hard-working. In his writings, Leroy does not hesitate to detail the reverse, as in the elopement of the already married Barbara Zehr (v. 2, 134), the involvement in politics of Emanuel Zimmerman as Justice of Peace, judge, and member of the assembly (v. 1, 252), the resistant act of Barbara Yoder chopping at the hands of the Indians trying to gain entrance through her open cabin window (v. 1, 313), and the questionable business dealings and quick temper of Joseph Stuckey, whose church ultimately removed him from the ministry (v. 2, 202).

A difference between Unser Leit and writings by authors outside of the plain churches is the outside writer's inability to be as concise in describing how the Amish feel about their relationship with Christ and their salvation. Leroy does this well on pages 392 and 393 of volume two.

The compilation and publication of Unser Leit was an immense labor of research, years of letters, trips, and study of books and writings to present a history of the Amish that appeals to the Amish. Amish can read about their ancestors in a complete work for the first time in an edition designed for them vs. a history destined to be known for its literary-scholarly value. The history of the Amish beginnings, their land, their trials, the circumstances that have defined them, and the foundation their forefathers laid will serve to give the Amish reader a deeper appreciation for the Ordnung (church rules) and the effort our leaders have expended on preserving our distinctives.

The amazing amount of splits occurring in the 1900s led to all levels of Amish, from Swartzentruber Amish that wear copper rings for rheumatism to the sect of people with no outward vestige of Amish background. Only their understanding of Amish church diversities divides these former Amish from the "English.” Leroy does not give a definite conclusion or reason for the large amount of Amish departing from conservative Amish churches in the 1900s. They were influenced by Pietism, Dunkards, and revival meetings; but most Amish feel the danger lies within the fold. The lack of practicing Christian principles is as much a factor in the destruction of Amish culture as worldly influences.

Some noticeable graphical errors were present, but did not take away from the experience. Nothing can be said about grammatical errors, since some would not be errors if translated into "Deutsch," and my own German-geared mind is not inclined to pick out violations of the English language.

An era I felt could have been included is the direction the Amish are headed in the last ten years. Almost anything will be tolerated in some districts because people don't want to offend others. It might affect their level of comfort or popularity. Amish own anything from laptops to 
radios, known or unknown to the congregation. It is an era of tolerance, "set your own convictions," church with the full spectrum of liberal and conservative well represented, and an era of immodesty. In this era, people are lax in enforcing the "ban," have rules without discipline, and leave the church of their upbringing for churches that allow more technology or worldly goods. If the Amish keep dropping the important acts that serve to set them apart, they will not be long in merging with mainstream America.

In conclusion, Unser Leit serves the author's intent well and should be an addition to every Amish home library for its value as a personal history and as a reminder of the strength and convictions that were present and necessary in the formation of our heritage.

\section{Review \#2}

Christopher G. Petrovich

Old Order Amish

Niška Banja, Serbia / Pearisburg, Virginia, USA

Leroy Beachy, a native of Holmes County, Ohio, and member of a conservative AmishMennonite congregation, has gathered the fruit of his prodigious labors between the elegant covers of two thick volumes. The result is a wide-ranging account narrating the Amish story through its various episodes on both sides of the Atlantic. He has written as a genealogist interested in the preservation, and at times restoration, of what he considers the main themes and emphases of traditional Anabaptist piety (vii). He has recounted the history of the Amish in story form, without the usual chapter divisions or section headings. So it is not a scholarly monograph. But Beachy does not claim to have written a scholarly text, even noting that “... when the writing of the text was begun in 1988, the eight-grade-education author was unaware of the importance of footnote documentation of sources...” (x) Therefore, I will review it in light of what it claims to be, that is, a denominational history retelling the story of a particular people who, in spite of “spiritual weaknesses” (viii) have preserved an “'authentic’ Christianity.” (x)

Unser Leit is structured chronologically as well as thematically. Beachy begins by introducing several key figures-Hans Landis, Uli Waggeman, Heinrich Frick, and Ulrich Müller - that acted as conduits of Christian piety, transmitting the zeal of Zurich Anabaptism to the emerging Amish movement, whom he believes should more appropriately be referred to as Oberländers (v. 1, 1-24). In chapters two and three he explores the decades leading up to the Mennonite / Amish division, proposes an earlier date for the emergence of the Oberländer (Amish), and sketches moves that Amish persons made within Europe-largely efforts to find local authorities that would permit greater freedom of worship and impose less burdensome taxation (v. 1, 25-228). Beachy then focuses on eighteenth-century migration to North America and their early years on the American frontier (v. 1, 233-331). Chapters five and six cover moves 
made within North America that have so significantly impacted Amish demographics down to the present day (v. 1, 337-451). The seventh chapter describes nineteenth-century migration to the New World in considerable detail, including a helpful 22-page chart listing all known immigrants, specifics of identity, their place and date of entry, and locations where they originally settled (v. 2, 1-212). Chapter eight (v. 2, 235-393), entitled "Reasons to Believe," endeavors to "follow through history the various ideas, events and processes that have shaped the Amish faith and mentality, both in how it conforms to or differs with that of other Christians or non-Christians” (v. 2, 235). Beachy concludes with a chapter devoted to the twentieth century, ominously identified as the "Century of Division” (v. 2, 395-473).

Several features distinguish Beachy's work from previous attempts to tell the Amish story. First, in spite of his desire to find common threads running through the history of the Amish people, Beachy recognized that diversity has also characterized Amish life. This is in marked contrast to previous attempts to tell the Amish story, particularly Steven Nolt's A History of the Amish (1992). Although book-length sociological studies published in the past decade have done much to redress this situation, this is the first time that diversity has appeared as a key component in a broad historical portrait.

Since Holmes County, Ohio, is the largest and most diverse Amish community, it is surprising that no one had written an account of its history. Fortunately, Beachy has done much to remedy this situation. But in focusing on the diversity that has come to characterize Holmes County in the twentieth century, he gives the impression that the North American Amish experienced church divisions like never before. The twentieth century was not all that much different than previous centuries, especially if we would know more about the ecclesiastical affairs of Amish churches in Europe during the eighteenth and nineteenth centuries. And neither Lancaster County, Pennsylvania, nor the Old Order Amish of Elkhart and LaGrange Counties, Indiana, experienced the multiplication of identities that occurred in Holmes County during this period. Not to mention that the rising number of sub-groups has generally corresponded with population growth. The 'Great Schism' should be seen for what it was, a conglomeration of local divisions that occurred over a period of multiple decades. And the divisions in central Pennsylvania that birthed the Byler and Nebraska Amish groups should be seen as links connecting the mid-nineteenth-century schisms with the Sam Yoder (Swartzentruber) division of the early twentieth century. Therefore, church divisions appear to be a characteristic of Amish church life, not a pattern that began in the twentieth-century as a result of the headstrong behavior of a few recalcitrant church leaders.

In the eighth chapter, Beachy frames the Amish experience Biblically and theologically but without neglecting relevant creeds, confessions, and disciplinary standards. In an attempt to depict non-resistance as an ancient practice of the children of God, he quotes the Authorized Version's rendering of the sixth commandment: “Thou shalt not kill” (v. 2, 238). But translators and interpreters have long recognized this as prohibiting murder rather than killing in general. Even more surprisingly, Beachy claims that "they were strictly forbidden to take the life of other 
men” (v. 2, 237) because the Noahic covenant forbids "shedding man's blood.” But he overlooks Genesis 9:5-6: “at the hand of every man’s brother will I [God] require the life of man.” So the Lord did not merely tolerate but actually commanded a certain type of human killing. And a further difficulty emerges: Who was expected to administer the death sentence? Since Anabaptists have traditionally shunned political involvement and declared that the sword is outside the "perfection of Christ" (Schleitheim Confession, 1527), it is difficult to imagine how they could have navigated these tangled circumstances. But this brings us to the crux of the issue. They would not have negotiated these tangled circumstances because they have traditionally denied that non-resistance is a teaching applicable to all ages. So Beachy bases his reading of certain Old Testament texts on premises that the Amish do not share, contradicting the developmental (eschatological) trajectory evident in Article 14 of the Dordrecht Confession. That is, non-resistance is a teaching of Jesus, the Old Testament prophet foretelling of a certain time when swords would be beat into plowshares. Although Beachy wants to champion the practice of non-resistance by commissioning Old Testament texts, he is forced to revise the eschatology of the Amish to make it work. Beachy's logic bears considerable resemblance to the "nonviolent God” perspective-Jesus fully reveals God; Jesus was nonviolent; therefore, God is nonviolent. Darrin Snyder Belousek (2014) has offered a compelling alternative to the "nonviolent God" position, a proposal much more consonant with the theological posture of the Amish.

The aspect most likely to be contested by historians is Beachy's revisionist reading of Amish beginnings. He claims that the Amish movement began several decades earlier than previously thought, a result of the evangelistic labors of Anabaptist minister Ulrich Müller in the Swiss Oberland region. Although this claim seems to be supported by certain circumstantial evidence and fits quite nicely within the broader narrative, it is difficult to imagine why Jacob Amman would have been sent on a mission to confront ministers in the Emmental region if they were distinct groups with differing origins. And why the confrontation so quickly became a heated exchange, resulting in expulsions and graphic denunciations. On the basis of letters written by Amman around the time of the division, I think Beachy goes a bit too far in turning the tables on mainstream Anabaptist historians for branding Jacob Amman a radical instigator of a splinter movement. There is certainly some truth in their assessment. In spite of these drawbacks, Beachy has done the reader a tremendous service by presenting the little bit that specialists know about the earliest history of the Amish movement, persuasively arguing that Hans Reist was an obdurate leader who deliberately resisted Amman's work in the Emmental region and thus should shoulder some of the responsibility for the Swiss Brethren division, and that the Amish have a very strong claim to being heirs of Swiss and Dutch Anabaptism.

If there was one significant way that Beachy could have furthered the average reader's grasp of the Amish story, it would have been by furnishing a nuanced account of the medieval (typically heretical) sects that most plain Anabaptists continue to claim as their forefathers in the faith, linking the sixteenth-century movement that began in Zurich to a pre-Constantinian golden age, or at least a time during which the "true church" existed on a wider scale and in a very 
visible, public manner, the way that Anabaptists think Christianity should disclose itself (see Article 8 of the Dordrecht Confession). Instead, Beachy recycled the old narrative of Anabaptism being linked to the early church by various heretical groups condemned by oppressive governing authorities (v. 2, 247-249), and at times overreaches in ascribing impious motives to certain persons and groups (v. 2, 250). Thankfully, he clearly disavowed the harsh tone that certain more fervently apologetic works evince.

In spite of the foregoing concerns, Beachy has accomplished what few other persons of Amish-Mennonite parentage have achieved. That is, he brought together a wide variety of Biblical and historical sources to explain how the life and faith of contemporary Amish communities could be viewed as deriving from the teachings of holy writ, and illustrate various ways the Amish have responded to new circumstances, the primary result being the continued fragmentation of Amish church life and repeated departure of small factions favoring broader acceptance of North American cultural norms. The primary implication of the final chapter is that the increasing divisiveness of Amish church life runs contrary to the unity of the Christian church.

Two more questions merit attention. First, how will the Amish receive this work? And secondly, how will it influence them? The most significant hindrances to broad dissemination are obvious - the length of the work (996 pages) and its cost (\$75). As a result, in my home community only two sets have been purchased and few have read more than snippets of the work. Nevertheless, I expect that the more evangelical sectors of the Amish will be energized by this work, as they have been by Beachy's writings in The Budget and elsewhere. An example is a recent article that appeared in Plain Interests encouraging plain Anabaptist communities to incorporate church history into their school curriculum. The article, written by an Old Order minister from an evangelical-minded community in Kentucky, repeatedly cited Unser Leit, identifying Beachy's revisionist account of Amish beginnings as a much-needed corrective to the standard Mennonite perspective. The author thought Unser Leit could shape the Amish people in positive ways, and perhaps even help to stem defection to more progressive church groups that do not identify with Jacob Amman, who has frequently been considered, by Amish and nonAmish alike, impulsive and headstrong.

It is difficult to forecast precisely how this work will be received by Amish persons who are not so attuned to evangelical emphases. I suspect that the mainstream Amish, that is, those not overtly evangelical or especially opposed to evangelical emphases, will embrace and appropriate this work to a certain extent. After all, it is much more than a clarion call for evangelical piety. And Beachy's writings do not merely energize evangelicals. They reach many outside the Old Order mainstream. For example, an acquaintance living in a community that originated from, and remains in partial fellowship with, exceptionally traditional Kenton (Ohio) once sent me clippings from Beachy's writings in The Budget. But I do not expect this twovolume set will gain a wide reception among the most conservative Amish groups, and for two reasons. First, an inverse correlation exists between the conservatism of church groups and 
educational achievement. And secondly, there is also an inverse correlation between the conservatism of the church group and income, making it less likely they will acquire the work. Therefore, I expect Beachy's work will be received most warmly by the New Order Amish, will appear somewhat commonly in the homes of the mainstream Amish (particularly among those in ministerial offices), and less frequently in Andy Weaver Amish homes. I expect reception to decline rapidly among those of the most conservative persuasion. Nevertheless, the breadth of the work will at times offset the most obvious hindrances to its reception, particularly among those engaged in genealogical research.

I believe that Unser Leit will influence the Amish in at least two significant ways. First, I expect that Amish ministers will become more conversant in the history of their religious tradition. I do not anticipate a major revolution because their view of education, as well as busy family lives and ministerial duties, will keep them from following too inquisitive a path. Nevertheless, I expect that more Amish persons will begin to examine their religious heritage because the subject now appears more comprehensible, as well as appealing. Second, I believe that the Amish world will become more evangelical in hue. Since few Amish persons have critical reading skills, as they read Beachy's work they will slowly and subconsciously come to imbibe a more evangelical spirit. But he is not trying to subtly subvert the Amish because, as Gerald J. Mast (2012) has noted, Beachy largely vindicates choices made by the Old Order and conservative Anabaptist communities. Nevertheless, Beachy is hoping to foster a more evangelical and historically-conscious mindset. Therefore, the success of Unser Leit will not only be measured by its success in gathering a wide variety of information to form a coherent, intelligible narrative that describes the Amish experience on both sides of the Atlantic, but also its ability to prescribe a particular view of Amish life that is not presently normative among the Amish themselves.

\section{References}

Belousek, Darrin Snyder. 2014. "God and Nonviolence: Creedal Theology and Christian Ethics.” Mennonite Quarterly Review 88(2):233-69.

Mast, Gerald. 2012. "Review of Unser Leit...The Story of the Amish.” Mennonite Quarterly Review. 86(2):265-69.

Nolt, Steven. 1992. A History of the Amish. Intercourse, PA: Good Books. 


\section{Author's Comments}

\section{Leroy Beachy}

Berea Amish-Mennonite Fellowship

Holmes County, $\mathrm{OH}$

Unser Leit: The Story of the Amish came about as a compelling burden to retell the story of "our people" (unser Leit) from the time of the founding in Switzerland in the latter third of the 1600s to the year 2000 in America.

Even while yet of preschool age, I had perceived that being "Amish" meant that we were somehow different from half of the customers in grandfather's harness shop. It was in first grade in school (which I shared with one Amish girl and thirteen others with strange family names like Flinner, Funk, and Bentz) when I learned that being different could cause problems. At recess one day, Lowell Hostetler, a Mennonite boy, informed me I can't play with the other boys because I was "Amish." It was then that Doran Horrisberger, a Reformed boy, insisted that I can play with them because I was only "half-Amish." With that label, I somehow made it through the eight grades, but always with a lingering question of the "who, what, and why" concerning unser Leit that set us apart. One detail I did learn along the way was that we were named after Jacob Amman, but who was he?

Continually in search of answers, by age $30 \mathrm{I}$ had learned quite by chance that the Amish were "Anabaptists" and their origin was in Switzerland. Having learned that, by age $40 \mathrm{I}$ had acquired a collection of Mennonite history books, from which, in seven excerpts from chapters relating to "The Amish Division," I was informed that "Jacob Amman was a ruthless," "Swiss bishop," "who took it upon himself," "to convince others of his own ideas." "It is plain that he was the cause of the division," "in which his group separated from the Mennonites," "and in his rage he excommunicated all the Swiss ministers." Such information was of no great comfort to one in search of his heritage.

The compelling burden to retell the Amish story came about with the eventual discovery that each of these seven excerpts, the gist of which was constantly being repeated over and over again in books and newspaper articles, were untrue.

In notable contrast to the "historians" who were depending on secondary information (simply repeating what others had said before them) were three prominent Mennonite historians whose writings were based on primary information (gleaned from archival records). In his book, Bernese Anabaptists, Delbert Gratz reported a "great expansion of numbers" of an outbreak of Anabaptism "in the Thun and Oberland regions of Bern in the seventeenth century [...] the exact circumstances of which [...] are not clearly known." Fifty years later, the Swiss Mennonite historian Hans Peter Jecker wrote of "a growing unrest in Bern in the last third of the seventeenth century,” specifically “a threatening outbreak of Anabaptism.” Almost simultaneously, the 
French Mennonite historian Robert Baecher reported findings that "a new generation of Anabaptists appeared on the scene, an a movement the scope of which had never been attained in Steffisburg."

How that the answer to the observations that had baffled the three primary source historians and a new concept of the founding of the Amish, including a different man as founder, as well as a generation-earlier beginning, began to be revealed by way of the collection of German letters an elderly Amishman kept in a shoe box, is explained in the preface of Unser Leit. The resulting new concept of the founding of the Amish is indeed a fascinating story, and hopefully far more conducive to the appreciation of one's heritage than the "seven excerpt theory."

How would such a revisionist approach to the often-related Amish story be received if published? There was no way to know but simply to take the risk and find out. Very few Amish have ever paid \$75 for a book, so would a two-volume set of a thousand pages bound in leatherlike hard cover inserted in a handsome slip case sell for that price? One comment heard by way of the grapevine was a college professor's remark: “They will never sell at that price.” Well, thankfully, they did. In three years, the 5,000 sets (a semi-trailer load) were sold out.

As for acceptance of the revision, much less negative response came through than expected, apparently because the pictorial inclusion of archival documents served well to verify the revision. There has been very little critical feedback; since one can learn from critique, I had actually hoped for more. The second reviewer's critique is what this author has been waiting for since the book first appeared: an honest evaluation and a balancing of critical observations (e.g. Beachy "goes a bit too far in turning the tables on mainstream Anabaptist historians" and "at times overreaches in ascribing impious motives to certain persons”) with compliments (e.g. "he clearly disavowed the harsh tone that certain more frequently apologetic works evince" and "I believe that Unser Leit will influence [...] Amish ministers [to] become more conversant in the history of their religious tradition.”

Far more common were the positive remarks, all of which can quite well be summed up in the comment of a local Amish bishop who met me at the mailbox: "That book is what we need. Now we know who we are.” Nothing could better describe the book's intent than those last six words. Those who took notice of the eighth-grade educated author's lack of proper punctuation, etc., may be consoled that a second edition, extensively revised in that respect, is on its way and will hopefully be available by mid-summer 2015. 